\title{
ENHANCING THE COMPETITIVENESS OF PRODUCTION OF ENTERPRISES OF AGRICULTURAL SPHERE
}

\author{
O. Pietukhova, A. Koniaha \\ National University of Food Technologies
}

\begin{tabular}{l}
$\quad$ Key words: \\
Competitiveness \\
Competitiveness of \\
products \\
Enterprise \\
Market \\
Quality \\
Canning industry \\
\hline
\end{tabular}

Article history:

Received 16.01.2018

Received in revised form

01.02 .2018

Accepted 14.02.2018

Corresponding author:

O. Pietukhova

E-mail:

ompetukhova@bigmir.net

\begin{abstract}
The importance of the competitiveness criterion of products and enterprises in their struggle on the domestic and world markets is considered. It is noted that domestic enterprises can only function effectively with the implementation of fundamentally new approaches for managing products competitiveness and with formation of a competitive strategy. It is proved that the problem of increasing the products competitiveness of Ukrainian enterprises is very actual, it acquires new meanings and requires a new understanding and solution.

The theoretical aspects of competitiveness and the main directions of increasing the products competitiveness are considered. The market of fruit and vegetable canning products is investigated and the conclusion about production decreasing, costs increase, quality of products decrease, assortment narrowing, prices increase, loss of traditional markets is made. The causes of deterioration in the industry are determined.

The basic activity principles and products competitiveness of the Ukrainian producer Mogilev-Podolsky cannery Private Company on the national and foreign markets are analyzed. The main competitors of the company are determined on the domestic and foreign markets, a comparison is made with competitors in the domestic market, the matrix of the competitive profile is constructed, and the strengths and weaknesses, opportunities and threats of the plant are identified. It was substantiated that MogilevPodolsky cannery Private Company has sufficient potential for increasing production volumes and ways to increase the competitiveness of its products both on the domestic and foreign markets are suggested. A conclusion is made regarding the increase of competition between enterprises in the context of global integration processes deepening. That is why it is extremely important for enterprises not only to produce high-quality products, but also to apply other ways to increase the competitiveness of their products on the market.
\end{abstract}

DOI: $10.24263 / 2225-2924-2018-24-1-8$ 


\title{
ПІДВИЩЕННЯ КОНКУРЕНТОСПРОМОЖНОСТІ ПРОДУКЦІї ПІДПРИЄМСТВ АГРОПРОДОВОЛЬЧОЇ СФЕРИ
}

\author{
О.М. Пєтухова, А.В. Коняга \\ Національний університет харчових технологій
}

У статті озглянуто значення критерію конкурентоспроможності продукиї та підприємств у їх боротьбі на внутрішніх $i$ світових ринках. Зазначено, ще вітчизняні підприємства можуть ефективно функиіонувати лише при втіленні принципово нових підходів до управління конкурентоспроможністю продукиії $і$ формування конкурентної стратегії. Доведено, що проблема підвищення конкурентоспроможності продукиії підприємств України є досить актуальною, набуває нового змісту $і$ вимагає нового іï осмислення та розв'язання.

Розглянуто теоретичні аспекти конкурентоспроможності та основні напрями підвищення конкурентоспроможності продукиії. Досліджено ринок плодоовочеконсервної продукиї, визначено причини зменшення випуску продукиії, зростання витрат на ї̈ виготовлення, зниження якості виробів, звуження асортименту, підвищення иін, втрати традиційних ринків збуту, а також погіршення становища в галузі.

Проаналізовано основні засади діяльності та конкурентоспроможність продукції українського виробника ПрАТ «Могилів-Подільський консервний завод» на національному та зовнішньому ринку. Визначено основних конкурентів підприсмства на внутрішньому та зовнішньому ринку, проведено порівняння 3 конкурентами на внутрішньому ринку, побудовано матриџю конкурентного профілю, а також виявлено сильні та слабкі сторони, можливості та загрози заводу. Обтрунтовано, що ПрАТ «Могилів-Подільський консервний завод» має достатній потениіал для збільшення обсягів виробництва, та запропоновано шляхи підвищення конкурентоспроможності його продукиї як на внутрішньому, так $i$ на зарубіжному ринках. Зроблено висновок щодо посилення конкурениії між підприємствами в умовах поглиблення світових інтеграиійних прочесів. Саме тому для підприсмств надзвичайно важливим є не лише виробництво якісної продукиії, а й застосування інших способів підвищення конкурентоспроможності своєї продукиії на ринку.

Ключові слова: конкурентоспроможність, конкурентоспроможність продукиії, підприємство, ринок, якість, консервна промисловість.

Постановка проблеми. Процеси глобалізації, що розвиваються у світі, значно підсилюють значення критерію конкурентоспроможності продукції та підприємств у їх боротьбі на внутрішніх і світових ринках. На основі цих процесів у зарубіжних країнах здійснюється широкомасштабне впровадження висококреативних моделей управління конкурентоспроможністю продукції, виокремлення його у самостійну систему та перетворення в одне 3 найбільш пріоритетних завдань державної політики. 
У жорсткому конкурентному середовищі вітчизняні підприємства можуть ефективно функціонувати лише при наявності механізму забезпечення стійкого стану на ринку, тобто при втіленні принципово нових підходів до управління конкурентоспроможністю продукції і формування конкурентної стратегії.

У сучасній конкурентній боротьбі, за всієї ії гостроти та динамізму, виграє той, хто аналізує та змагається за свої конкурентні позиції. Процес забезпечення конкурентоспроможності $\epsilon$ невід'ємним етапом стратегічного управління підприємством і пов'язаний з вирішенням проблеми найшвидшого досягнення запланованих результатів в умовах мінливого внутрішнього середовища та ситуації на ринку [9].

У результаті трансформаційних процесів в економіці України послабилися організаційні основи управління конкурентоспроможністю вітчизняних підприємств та продукції і саме це стало загрозою їх витіснення конкурентами на внутрішньому ринку України і на зарубіжних ринках. Саме тому проблема підвищення конкурентоспроможності продукції промислових підприємств України є досить актуальною, набуває нового змісту і вимагає нового іiі осмислення та розв'язання.

Враховуючи зазначені обставини, необхідне наукове обгрунтування нових засад забезпечення конкурентоспроможності продукції і розроблення на цій основі методичних положень і практичних рекомендацій, спрямованих на досягнення та збереження стійких конкурентних позицій підприємств у динамічних умовах макроекономічного середовища, та визначення шляхів удосконалення управління конкурентоспроможністю продукції українських підприємств на зовнішньому та внутрішньому ринку.

Аналіз останніх досліджень і публікацій. Дослідження теоретикометодичних основ та практичного застосування управління конкурентоспроможністю знайшли своє відображення в працях зарубіжних учених Г. Асселя, Ф. Котлера, Г. Мінцберга, М. Портера, Ф. Тейлора, А. Сміта, А. Файоля, Р. Уотермена, Е. Чемберлена, Й. Шумпетера та багатьох інших. Дослідженню проблем конкурентоспроможності підприємства присвячено праці: Г. Азоєва, І. Ансоффа, О. Градова, Р. Фатхутдінова, А. Юданова та інших. У працях вітчизняних учених Я.Б. Базилюка, В.А. Білошапки, Н.М. Гаращенка, В.І. Герасимчука, В.Л. Діканя, О.І. Драган, Г.В. Загорій, Ю.Б. Іванова, О.П. Манзій, Г.В. Осовської, Г.М. Скударя, О.Б. Чернеги та багатьох інших приділяється значна увага формуванню конкурентних переваг і конкурентоспроможності продукції та підприємств.

Однак, незважаючи на значні досягнення в теорії й практиці управління конкурентоспроможністю продукції, є проблеми, які залишаються предметом дискусій і обговорень вчених-економістів, зокрема складність і багатоаспектність проблеми забезпечення конкурентоспроможності продукції підприємств агропродовольчої сфери вимагає подальших наукових досліджень.

Мета статті: оцінювання конкурентоспроможності українського виробника ПрАТ «Могилів-Подільський консервний завод» на національному та зовнішньому ринку, аналіз його діяльності та побудова матриці конкурентного профілю, а також визначення напрямів і шляхів підвищення конкуренто- 
спроможності продукції вітчизняних підприємств на внутрішньому та зовнішньому ринках.

Викладення основних результатів дослідження. Терміни «конкуренція», «конкурентоспроможність», «конкурентні переваги», «конкурентоспроможність товару», «конкурентоспроможність підприємства» тощо все частіше використовуються в сучасній економічній літературі, оскільки без знання цих економічних категорій неможливо вирішити сучасні економічні проблеми. Конкурентоспроможність як економічне явище втілює широке наукове і практичне усвідомлення процесів конкуренції як одного із ключових параметрів функціонування ринкової економіки і саме тому для реформування економіки України в напрямку створення повноцінного конкурентного середовища та розвитку конкурентних відносин необхідне дослідження поняття «конкуренція».

Основним інструментом регулювання ринкової економіки $є$ конкуренція, суть якої полягає в боротьбі між підприємствами, що виступають на ринку 3 метою забезпечення кращих можливостей збуту своєї продукції, задоволення різноманітних потреб покупців і одержання найбільшого прибутку [1].

Конкуренцію слід розглядати як примусову силу, яка змушує підвищувати продуктивність праці, прискорювати НТП, збільшувати масштаби виробництва, впроваджувати нові форми організації виробництва тощо, оскільки вона $є$ об'єктивним економічним законом розвинутого товарного виробництва, в результаті чого виступає важливою рушійною силою розвитку економічної системи, складовою частиною ії господарського механізму [2].

Конкуренція існує у будь-якій країні з ринковою економікою та в будьякій галузі. Якщо говорити про ринок плодоовочеконсервної продукції, то можна сміливо сказати, що він насичений продукцією. Варто врахувати, що для України питання забезпечення населення плодоовочеконсервною продукцією особливо актуальне, оскільки в країні з високим аграрним потенціалом рівень виробництва сільськогосподарської продукції і ії переробки оцінюється як вкрай незадовільний. Водночас, якщо порівняти розвиток плодоовочеконсервного виробництва до і після 1990 р., то можна зробити висновок, що в період реформування національного господарства зменшився випуск продукції, зросли витрати на ії виготовлення, знизилась якість виробів, звузився асортимент, підвищились ціни, втрачено традиційні ринки збуту. Основними причинами погіршення становища в галузі стало скорочення вирощування основних видів сільськогосподарської сировини, недостатня увага $з$ боку держави до розвитку консервної галузі, недосконалість економічного механізму господарювання у період формування розвинутих ринкових відносин, руйнування фінансово-кредитної і платіжної системи, розрив економічних зв'язків з країнами-експортерами консервних виробів.

Основними виробниками плодоовочевих консервів в Україні є: компанія «Чумак», яка займається консервуванням овочів, виготовленням соків та інших видів плодовоовочеконсервної продукції; група компаній «Верес», яка займається консервуванням овочів за особливою технологією - консервування «по-домашньому»; ПАТ Виробниче об'єднання «Одеський консервний завод» (торговельна марка «Господарочка») — виготовляє овочеві та плодові 
консерви, соки, пюре, кетчупи, халву та рибні консерви; ТОВ «Ніжинський консервний комбінат», що виготовляє консервацію, соуси, соки, соління; ПАТ «Вінницький консервний завод» - займається виготовленням ікри, варення, джемів, повидла, овочевих консервів, рибних та м'ясних консервів, томатних соусів і кетчупів; компанія «Сандора» - займається виготовленням найрізноманітніших соків 3 плодів та ягід; ПрАТ «Одеський консервний завод дитячого харчування», що входить у великий соковий холдинг «Вітмарк-Україна» (його соки в білій упаковці займають більше 14\% сокового ринку України, а дочірнє підприємство «ВКС-Соки» виготовляє соки та продає їх за доступними для споживача цінами); консервний завод «Іллічівський» - займається виробництвом плодоовочевих консервів; «Вінніфрут»займається виготовленням фруктових та овочевих соків 3 натуральних продуктів.

Лідируючі позиції на ринку Вінницької області займає ПрАТ «МогилівПодільський консервний завод» - сучасне підприємство харчової промисловості, оснащене високопродуктивними лініями з виробництва фруктових, овочевих консервів, соків-концентратів.

Конкурентоспроможність підприємства визначається конкурентоспроможністю його конкретних товарів i/або послуг, виробничим і трудовим потенціалом, ефективністю системи управління та вимірюється визначеними ключовими показниками (індикаторами), які адекватно характеризують його стан і динаміку та використовуються для прийняття управлінських рішень менеджерами підприємства щодо підвищення рівня конкурентоспроможності [11].

3 метою визначення рівня конкурентоспроможності ПрАТ «Могилів-Подільський консервний завод» порівняємо підприємство з його основними конкурентами на вітчизняному ринку (ПрАТ «Виробниче об'єднання «Одеський консервний завод»»), ПАТ «Новоушицький консервний завод» (Львівська обл.), ПАТ «Білоцерківський консервний завод» (Київська обл.)) за допомогою матриці конкурентного профілю (табл. 1), для побудови якої як експерти були задіяні фахівці ПрАТ «Могилів-Подільський консервний завод».

Таблиия 1. Матриця конкурентного профілю, складено авторами на основі проведених досліджень

\begin{tabular}{|c|c|c|c|c|c|c|c|c|c|}
\hline \multirow[t]{2}{*}{$\begin{array}{c}\text { Ключові фактори } \\
\text { успіху }\end{array}$} & \multirow[t]{2}{*}{$\begin{array}{l}\text { Вагові } \\
\text { коефі- } \\
\text { цієнти }\end{array}$} & \multicolumn{2}{|c|}{$\begin{array}{c}\text { ПрАТ } \\
\text { «Могилів- } \\
\text { Подільський } \\
\text { консервний } \\
\text { завод» }\end{array}$} & \multicolumn{2}{|c|}{$\begin{array}{c}\text { ПрАТ } \\
\text { «Виробниче } \\
\text { об’єднання } \\
\text { «Одеський } \\
\text { консервний } \\
\text { завод»» }\end{array}$} & \multicolumn{2}{|c|}{$\mid \begin{array}{c}\text { ПАТ } \\
\text { «Новоушицький } \\
\text { консервний } \\
\text { завод» }\end{array}$} & \multicolumn{2}{|c|}{$\begin{array}{c}\text { ПАТ } \\
\text { «Білоцерків- } \\
\text { ський } \\
\text { консервний } \\
\text { завод» }\end{array}$} \\
\hline & & ранг & оцінка & ранг & оцінка & ранг & оцінка & ранг & оцінка \\
\hline 1 & 2 & 3 & 4 & 5 & 6 & 7 & 8 & 9 & 10 \\
\hline Ціна продукції & 0,1 & 8 & 0,8 & 9 & 0,9 & 7 & 0,7 & 8 & 0,8 \\
\hline Канали розподілу & 0,2 & 10 & 2 & 10 & 2 & 8 & 1,6 & 7 & 1,4 \\
\hline $\begin{array}{c}\text { Охоплення ринку } \\
\text { продукцією }\end{array}$ & 0,1 & 9 & 0,9 & 9 & 0,9 & 6 & 0,6 & 8 & 0,8 \\
\hline $\begin{array}{c}\text { Рівень реклами } \\
\text { продукції }\end{array}$ & 0,075 & 8 & 0,6 & 8 & 0,6 & 7 & 0,525 & 8 & 0,6 \\
\hline
\end{tabular}


Продовження табл. 1

\begin{tabular}{|c|c|c|c|c|c|c|c|c|c|}
\hline 1 & 2 & 3 & 4 & 5 & 6 & 7 & 8 & 9 & 10 \\
\hline $\begin{array}{c}\text { Кваліфікація } \\
\text { персоналу }\end{array}$ & 0,1 & 9 & 0,9 & 9 & 0,9 & 9 & 0,9 & 6 & 0,6 \\
\hline $\begin{array}{c}\text { Продуктивність } \\
\text { технологій }\end{array}$ & 0,05 & 8 & 0,4 & 10 & 0,5 & 9 & 0,45 & 8 & 0,4 \\
\hline $\begin{array}{c}\text { Рівень } \\
\text { менеджменту }\end{array}$ & 0,05 & 9 & 0,45 & 9 & 0,45 & 5 & 0,25 & 6 & 0,3 \\
\hline Якість продукції & 0,2 & 10 & 2 & 10 & 2 & 9 & 1,8 & 7 & 1,4 \\
\hline $\begin{array}{c}\text { Прибутковість } \\
\text { підприємства за } \\
\text { рахунок реалізації } \\
\text { продукції }\end{array}$ & 0,1 & 8 & 0,8 & 10 & 1 & 0 & 0 & 7 & 0,7 \\
\hline $\begin{array}{c}\text { Надійність } \\
\text { продукції }\end{array}$ & 0,025 & 10 & 0,25 & 9 & 0,225 & 10 & 0,25 & 9 & 0,225 \\
\hline Загальна оцінка & 1,0 & & 9,1 & & 9,475 & & 7,075 & & 7,225 \\
\hline
\end{tabular}

3 матриці конкурентного профілю бачимо, що лідером у групі підприємств є ПрАТ «ВО «Одеський консервний завод»», на що вплинули географічне місце розташування, розміри підприємства, імідж компанії і багата сировинна база.

ПрАТ «Могилів-Подільський консервний завод» на другому місці в рейтингу, однак незначно поступається лідеру і має достатній потенціал для збільшення обсягів виробництва.

Основними конкурентами ПрАТ «Могилів-Подільський консервний завод» на зарубіжному ринку є Вітебський плодоовочевий комбінат (Білорусія), Гродненський консервний завод (Білорусія), ПАТ «Турів» (Білорусія), Баховський консервноовочесушильний завод (Білорусія), Келерашський консервний завод (Молдова), Кантемирський консервний завод (Молдова), ПАТ «Natur Bravo» (Молдова), ПАТ «Агросфера-БМ» (Молдова), ПАТ «Вак-плод» (Польща), ПАТ «Бастіон-фрут» (Польща), ПАТ «Санлакол» (Ізраїль), ПАТ «Вітелі-фуд» (США), ПАТ «Randall Food Products» (США), французькі компанії «Bonduelle Group», Le Groupe Cecab (TM D'Aucy), американська General Mills, німецька Lorado International $\mathrm{GmbH}$.

Порівнюючи ПрАТ «Могилів-Подільський консервний завод» 3 конкурентами, можна виділити його сильні і слабкі сторони, можливості і загрози, які наведені у табл. 2.

Таблиця 2. SWOT-аналіз ПАТ «Могилів-Подільський консервний завод», складено авторами на основі проведених досліджень

\begin{tabular}{|c|c|}
\hline Сильні сторони $(S)$ & Слабкі сторони $(W)$ \\
\hline 1 & 2 \\
\hline $\begin{array}{c}\text { Контроль над значною часткою ринку } \\
\text { консерв (домінування) у м. Могилів- } \\
\text { Подільський (60-70\%); }\end{array}$ & $\begin{array}{c}\text { Недостатня прибутковість через високі } \\
\text { витрати на упаковку та склотару. }\end{array}$ \\
\hline $\begin{array}{c}\text { Відносно низький рівень конкуренції } \\
\text { виробників консерв }\end{array}$ & $\begin{array}{c}\text { Наявність застарілого, енергозатратного } \\
\text { устаткування на підприємстві, необхідність } \\
\text { ремонтів і перевірки технічного стану }\end{array}$ \\
\hline
\end{tabular}




\begin{tabular}{|c|c|}
\hline & Продовження табл. 2 \\
\hline 1 & 2 \\
\hline $\begin{array}{c}\text { Налагоджені ділові зв’язки зі споживачами } \\
\text { продукції і постачальниками сировини }\end{array}$ & $\begin{array}{l}\text { Сезонність виробництва та нестабільна } \\
\text { якість, що залежить від урожайності }\end{array}$ \\
\hline $\begin{array}{c}\text { Діяльність у прикордонній зоні та } \\
\text { можливість виходу на зарубіжні ринки }\end{array}$ & Відсутність ефективної служби маркетингу \\
\hline $\begin{array}{l}\text { Накопичений багаторічний виробничий } \\
\text { досвід роботи на ринку консерви }\end{array}$ & Недостатні оборотні активи \\
\hline $\begin{array}{c}\text { Можливість збільшення потужності вироб- } \\
\text { ництва за рахунок введених технологій }\end{array}$ & Недосконала система мотивації персоналу \\
\hline \multicolumn{2}{|l|}{ Висока кваліфікація персоналу } \\
\hline \multicolumn{2}{|l|}{ Високий імідж компанії та її визнання } \\
\hline Зовнішні сприятливі можливості $(\mathrm{O})$ & Зовнішні загрози підприємству (Т) \\
\hline $\begin{array}{c}\text { Можливість зайняти більшу частку ринку, } \\
\text { шляхом підвищення якості продукції }\end{array}$ & $\begin{array}{c}\text { Зростання рівня конкуренції; поступове } \\
\text { зниження попиту на основні види продукції }\end{array}$ \\
\hline $\begin{array}{c}\text { Можливість закуповувати сучасне } \\
\text { обладнання у зарубіжних фірм }\end{array}$ & $\begin{array}{c}\text { Нестабільність і недосконалість } \\
\text { законодавства (в т. ч. податкового) }\end{array}$ \\
\hline $\begin{array}{c}\text { Можливість розширення асортименту } \\
\text { продукції }\end{array}$ & $\begin{array}{l}\text { Низька інвестиційна привабливість } \\
\text { консервної галузі }\end{array}$ \\
\hline Автоматизація виробництва & Зміна потреб і смаків споживачів \\
\hline \multirow[t]{2}{*}{ Майбутні інвестиції } & $\begin{array}{c}\text { Зниження купівельної спроможності } \\
\text { споживача }\end{array}$ \\
\hline & Інфляція в країні \\
\hline
\end{tabular}

Простежити співвідношення факторів зовнішнього і внутрішнього середовища можна за допомогою матриці SWOT-аналізу, наведеної в табл. 3.

Таблиия 3. Матриця SWOT-аналізу ПАT «Могилів-Подільський консервний завод», складено авторами на основі проведених досліджень

\begin{tabular}{|c|c|c|c|}
\hline & \multicolumn{2}{|c|}{ Зовнішнє середовище } \\
\hline & & Можливості & Загрози \\
\hline \multirow{2}{*}{ 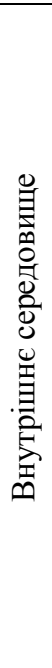 } & $\begin{array}{c}\text { Сильні } \\
\text { сторони }\end{array}$ & \begin{tabular}{|c|} 
поле СiМ: \\
- пошук лізингової схеми придбання \\
сучасного обладнання; \\
- використання позитивної ділової \\
репутації задля збуту консерв; \\
- виведення на ринок нових \\
прибуткових виробів; \\
- зміцнення ринкових позицій; \\
- залучення нових інвесторів
\end{tabular} & $\begin{array}{c}\text { поле Ci3: } \\
\text { - розширення представленості в } \\
\text { торговельній мережі } \\
\text { - зосередженість на виробництві } \\
\text { високорентабельних видів } \\
\text { консерви; } \\
\text { - утримання позитивного іміджу } \\
\text { - підвищення оборотності капіталу }\end{array}$ \\
\hline & $\begin{array}{c}\text { Слабкі } \\
\text { сторони }\end{array}$ & \begin{tabular}{|c|} 
поле СлМ: \\
- кредитування задля придбання \\
сучасного обладнання; \\
- оновлення автомобільного парку за \\
лізинговою схемою \\
- партнерство з виробниками \\
сучасного обладнання; \\
- збільшення прибутку за рахунок \\
отримання нових замовлень
\end{tabular} & $\begin{array}{c}\text { поле Слз: } \\
\text { - страхування ризиків зростання цін } \\
\text { на основну сировину; } \\
\text { - зниження витрат на виробництво } \\
\text { - оптимізація обсягів випуску } \\
\text { продукції }\end{array}$ \\
\hline
\end{tabular}

Проведений аналіз дає підстави стверджувати, що ПрАт «Могилів-Подільський консервний завод» має можливість домінувати на ринку плодоовочевої 
консерви, що дасть змогу отримати більший прибуток. Його спеціалізація на виробництві плодоовочевих консервів протягом багатьох років забезпечить пом'якшення загрози 3 боку сучасних автоматизованих підприємств, які стрімко розвивають власне виробництво консервних виробів. Проте низька інвестиційна привабливість і недостатня прибутковість виробничої діяльності створює реальну загрозу для підприємства як самостійної господарської одиниці і лише здешевлення кредитів, розвиток фінансового та фондового ринків дасть змогу оновити застарілі основні засоби і затратні технології виробництва.

Отже, для підвищення конкурентоспроможності й ефективності діяльності підприємства необхідно збільшити кількість замовлень шляхом підтримки існуючої системи збуту продукції та іiі розширення, що забезпечить підприємство постійними замовленнями. Обсяг замовлень можливо розширити за допомогою мережі Інтернет, просуваючи таким чином торговельну марку підприємства. Для цього необхідно оновити сайт підприємства 3 метою надання вичерпної інформації про продукцію заводу, оскільки існуючий нині сайт $\epsilon$ недостатньо інформаційним.

Крім того, основними напрямами підвищення конкурентоспроможності продукції ПрАТ «Могилів-Подільський консервний завод» та посилення його ринкових позицій $\epsilon$ :

- постійне вдосконалення продукції, підвищення ії якості, привабливості, економічності, сертифікації тощо;

- розширення асортименту продукції;

- виготовлення продукції за замовленням (ювілярам, сімейні);

- виробництво органічної продукції, що може стати дуже перспективним при виході на ринки СС;

- творче використання корисного досвіду конкурентів;

- розробка та впровадження інноваційних технологій, оновлення застарілої матеріально-технічної бази та застосування нових прогресивних методів управління;

- активне впровадження маркетингових досліджень, які $є$ запорукою успішної діяльності будь-якої компанії на ринку;

- стимулювання продажів за рахунок проведення різноманітних акцій, реклами; активізація рекламної діяльності в засобах масової інформації;

- зростання рівня професійної майстерності працівників та залучення нових висококваліфікованих фахівців;

- залучення додаткових інвестицій, особливо іноземних, для розширення можливостей підприємства, його підтримки та допомоги виходу на зовнішні ринки для реалізації продукції;

- вміле маніпулювання ціновими факторами конкурентної боротьби тощо.

Окрему увагу слід приділити розвитку експортного потенціалу та формуванню соціальної відповідальності бізнесу.

\section{Висновки}

Із поглибленням інтеграції України до світової спільноти все більше зростає конкуренція між підприємствами, їх боротьба за збільшення частки 
ринку та прихильність споживачів. Саме тому для підприємств надзвичайно важливим $є$ не лише виробляти якісну продукцію, а й застосовувати інші способи підвищення конкурентоспроможності своєї продукції на ринку, наприклад, різні засоби просування та популяризації товарів серед споживачів, перегляд своєї цінової політики, стеження за ринковими тенденціями.

Основною властивістю конкурентоспроможності є те, що вона показує, наскільки ефективно працює компанія для задоволення потреб своїх споживачів порівняно 3 компаніями-конкурентами на ринку. Рівень конкурентоспроможності товарів може бути чітко визначеним у той самий момент, коли товар потрапляє на ринок до споживачів і там фактично проходить перевірку на відповідність потребам та смакам покупців. Продукція, яка найбільше відповідає таким вимогам, і буде найбільш конкурентоспроможною серед відповідних ій товарів-аналогів. Проте потрібно пам'ятати, що те, що сьогодні подобається покупцю найбільше, може стати йому абсолютно непотрібним вже завтра, адже ми живемо в епоху технологічних інновацій, де все змінюється надзвичайно швидкими темпами. Тому для підприємства та підтримання його конкурентоспроможності на ринку необхідно знайти баланс між тим, чого прагне покупець, що він може забажати наступного дня та що підприємство може йому запропонувати.

\section{Література}

1. Василенко В.О. Виробничий менеджмент / В.О. Василенко, Т.І. Ткаченко. - Київ : ЦУЛ, 2005. - 532 с.

2. Владимирова Л.П. Прогнозирование и планирование в условиях рынка / Л.П. Владимирова. - Москва : Издательский Дом «Дашков и К», 2007. - 308 с.

3. Гарачук Ю.О. Підвищення ефективності діяльності підприємства за рахунок управління конкурентоспроможністю / Ю.О. Гарачук // Актуальні проблеми економіки. 2008. 一 № 2(80). - С. $60-65$.

4. Долюсанський I.3. Конкурентоспроможність підприємства : [навч. посібник] [Текст] / I.3. Должанський, Т.О. Загорна. - Київ : Центр навчальної літератури, 2006. - 384 с.

5. Єрмаков О.Ю. Формування ринку плодів в Україні / О.Ю. Єрмаков // Економіка АПК. — 2015. — № 4. - С.94-98.

6. Журба I.О. Сутність і значення конкурентоспроможності підприємства / I.О. Журба, Ю.М. Коляденко [Електронний ресурс]. - Режим доступу : http://archive.nbuv.gov.ua.

7. Конкурентоспроможність як складова економічної безпеки підприємства / О.О. Фальченко, Н.Б. Токарь // Вісник НТУ «ХПІ». Серія: Технічний прогрес і ефективність виробництва. - Харків : НТУ «ХПІ». - 2013. - № 67(1040). - С. 156-158.

8. Літвінова Ю.О. Проблеми забезпечення конкурентоспроможності підприємства в сучасних умовах / Ю.О. Літвінова // Управління розвитком. - 2012. — № 9. - С. 35-37.

9. Манзій О.П. Конкурентоспроможність підприємств агропродовольчої сфери / О.П. Манзій // Економіка харчової промисловості. - 2014. - № 3(23). - С. 17-20.

10. Оруба Б. Формирование системы единичных показателей оценки конкурентоспособности продукции / Б. Оруа // Економіст. - 2011. - №1. - С. 63 -65.

11. Осовська Г.В. Профіль конкурентоспроможності переробних підприємств / Г.В. Осовська // Ефективна економіка. — 2013. - № 4 [Електронний ресурс]. — Режим доступу : http://www.economy.nayka.com.ua/?op=1\&z=2288. 